\section{SOI: 1.1/TAS DOI: 10.15863/TAS International Scientific Journal Theoretical \& Applied Science}

Tatiana Nickolaevna Pasechkina Postgraduate Senior Lecturer at the department of foreign languages and culture of speech Siberian Fire Rescue Academy of the Ministry for Emergency Situations of Russia Zheleznogorsk Krasnoyarsk territory pasechkina@yandex.ru

Published: $20.12 .2017 \quad$ http://T-Science.org

SECTION 21. Pedagogy. Psychology. Innovations in the field of education.

\title{
THE PROBLEM OF FORMATION OF STUDENTS COMMUNICATIVE SELF-EFFICACY AT THE STAGE OF THEIR PROFESSIONAL TRAINING AT THE HIGHER EDUCATIONAL ESTABLISHMENT
}

Abstract: The article deals with the problem of the communicative self-efficacy of the person. The attention is paid to the development of this personal meta-quality among students and cadets at the stage of their professional training at the university. A brief analysis of theoretical approaches to understanding the phenomenon "communicative self-efficacy" is given. The relevance of the research is indicated in the context of looking for methods aimed to the formation of this meta-quality. The results of using techniques of critical thinking development are presented.

Key words: communicative self-efficacy, development of personal potential, peculiarities of modern students, professional training, methods of development of critical thinking.

Language: English

Citation: Pasechkina TN (2017) THE PROBLEM OF FORMATION OF STUDENTS COMMUNICATIVE SELF-EFFICACY AT THE STAGE OF THEIR PROFESSIONAL TRAINING AT THE HIGHER EDUCATIONAL ESTABLISHMENT. ISJ Theoretical \& Applied Science, 12 (56): 23-27.

\section{Soi: http://s-o-i.org/1.1/TAS-12-56-6 Doi: crossef https://dx.doi.org/10.15863/TAS.2017.12.56.6}

\section{Introduction.}

Nowadays, high demands are made to future specialists. Some personal qualities are more important than professional ones. These qualities are: the ability to use self-internal resources, the development of personal potential, that is, the desire for constant self-development, the ability to overcome difficulties, to cope effectively with situations of uncertainty, to choose necessary strategies of behavior and communication.

In this connection, the notion "self-efficacy" is heard in pedagogy and psychology very often. This concept determines the possibility of becoming a person as an active subject of his life, who is capable to estimate his own abilities and resources adequately on the hand and to reach the maximum acceptable results in various fields of activity on the other hand $[6, p$.60]. Within the framework of our research, the most actual issue is the studying and formation of communicative self-efficacy of students, cadets at the stage of their professional training at the higher educational establishment.

\section{The main text.}

Despite the available researches of the phenomenon "self-efficacy", the concept "communicative self-efficacy" is still not sufficiently developed in domestic scientific works. So M.I. Gaidar, according to his own understanding of selfefficacy, singles out activity, communicative and personal self-efficacy [3, p. 6]. He notes that communicative self-efficacy is a person's idea that he has such a communicative potential and experience which allows him to use different means of communication in combination with confidence that the person will be able to effectively implement them.

The work of T.V. Belykh is of great interest for our research. The scientist indicates that communicative self-efficacy refers to an unrealized personal potential, determining the way in which professional or educational activities will be realized, what strategies of implementation, style, individual characteristics of activity will be chosen for this [2, p. 5].

We, in our turn, consider the notion "communicative self-efficacy" of students as the ideas about their own forces and possibilities, the ideas about their ability to act effectively in situations of uncertainty, to choose effective strategies of behavior and communication, and also as a successful demonstration of their own

ISPC Generalization of scientific results, 
communication potential in different situations as well as development of this potential.

The results of our research [4] indicate the need for formation of students' communicative selfefficacy at the stage of their professional training at the higher educational establishment.

It should be also taken into account that in our high-speed multilevel society, controlled by computers and technologies, effective verbal communication is extremely necessary. It is important for modern employers that young specialists have developed communicative skills, the ability to correctly and logically construct their speeches. Public speaking is a necessary skill in the modern world. Specialists in different fields have to prepare and conduct lectures, presentations, participate in discussions, negotiations.

Unfortunately, quite often interesting content is lost under an inexpressive performance. Fears of the audience, stiffness, nervousness don't allow to achieve a good effect during a presentation or a business conversation. The ability to properly represent oneself, to structure information, to answer questions is a necessary condition for success in situations where an oral presentation of information is required. For successful public speech the following things are necessary: a positive emotional attitude to communication, public speaking skills, as well as thorough preparation which requires a deep understanding of the topic of the speech, and the elaboration of possible questions from the audience and the arguments.

All this requires from a student the ability to analyze, to choose the most optimal decisions, to reasonably refute the false, to question decisions and information, to understand the illogicality of statements and to react to them; to solve problem situations, to work in a group, to speak competently.

However, it's no secret that the development of digital technologies has made modern students a generation that has grown up in the digital environment. Unrestricted access to information gives them confidence in their views, which are not always correct.

The main distinguishing feature of the modern generation of students is clip thinking. They operate only with fixed-length meanings, which means they cannot focus on any information for a long time, they have a reduced ability to analyze. Today's students quickly get tired and lose attention, especially if the information is not very interesting; they prefer visual symbols to logic and deepening into the text.

It should also be noted that modern young people organize problem communication with great difficulty and generally cease to appreciate real communication. Being under the influence of various sources of information students, as a rule, are completely unaware where and how they got the information, why they suddenly start to speak this way, and not otherwise. They willingly enter into a language game on any subject, but they are not able to differ when they think for themselves and defend their own position, and when they only reproduce the information that was downloaded the day before.

The Internet hinders the formation of thinking of students. A computer creates the illusion that a person can penetrate into any space and act there. In fact, students find themselves in great difficulty when they have to set goals, interact with others, transmit their plan, implement it, re-formulate goals and design an action, based on already gained experience etc.

Organization of the educational process using the methods of development of critical thinking makes it possible to activate the cognitive activity of the students, to teach them to be critical about information, to prove their point of view reasonably, to correctly disagree with the opinions of others, to listen and to hear, to improve the ability of asking questions in order to obtain more accurate information or its verification. Orientation of students to develop critical thinking (through conversations, examples, focus on problem points) helps to realize that it is necessary to be wellinformed, to understand the views of others; to aim to expand own horizons; to show flexibility, persistence, readiness to correct own mistakes, to seek compromise.

The idea of using methods for developing critical thinking takes its roots from western pedagogics (Halpern D., Hell L., Ziegler D.J. Steele, K. Meredith, C. Temple [9;7]). It should be noted that the organization of the educational process, focused on the development of critical thinking, requires the teacher serious preparation, in-depth analysis of the material content, and a great erudition.

This article presents only a few methods of developing critical thinking that are most often used by us during the work with students and cadets at English classes.

A method "Tables" (graphical organization of the information, may be used at any stage of the lesson). The table "Know - Want to learn - Learn" is being drawn up. In the first column all the ideas on the issue are fixed; the controversial thoughts and questions that arose during the discussion on the topic are written in the in the second column, and the answers to the questions (after reading the text) are fixed in the third column. After filling in the table, it is necessary to compare what you knew before with the information obtained from the text. In this case it is desirable to present information, concepts or facts only in your own words, without quoting a textbook or other text that you worked with.

After independent or group work, the correctness of the completed material is discussed, clarification, addition, correction. 
A method "Composing a cluster" (pic.1) means the systematization of material in the form of a branching scheme, when semantic units of text are allocated, may be a method of motivation for reflection before studying a topic or a form of systematizing information when summarizing. This technique develops the ability to build predictions and substantiate them, helps to draw analogies, to make connections, to develop a skill of simultaneous consideration of several options which is necessary in solving life problems. It promotes development of system thinking.

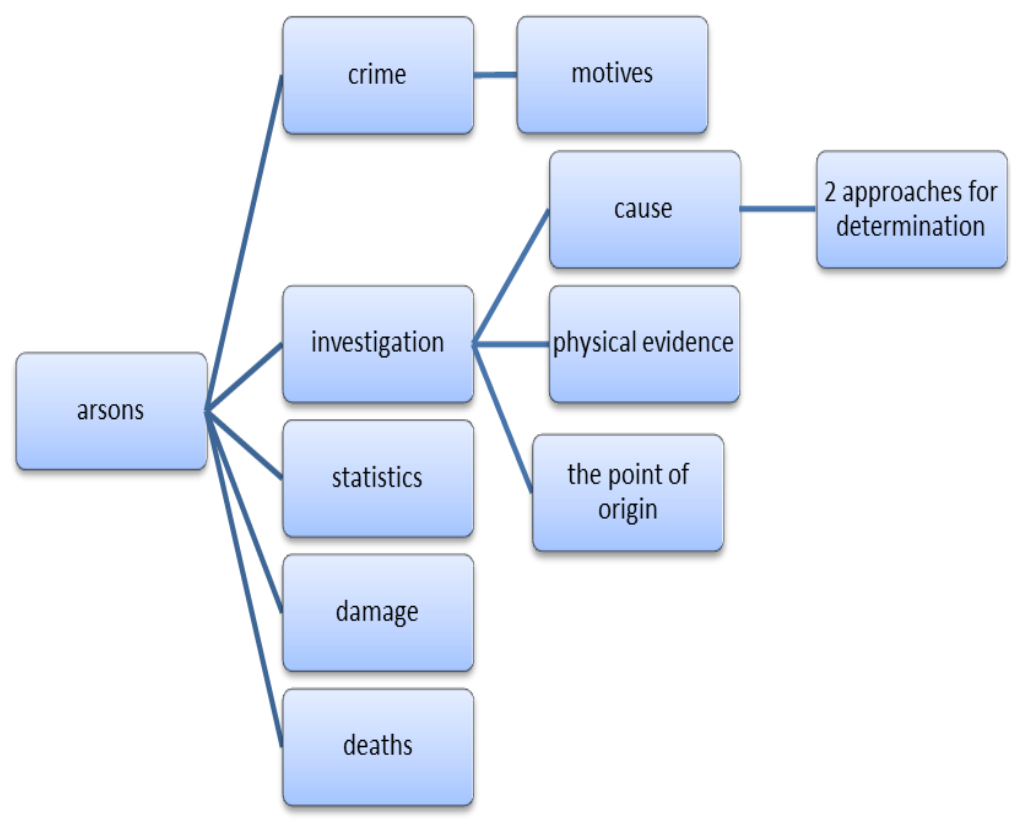

Picture 1 - Cluster "Arsons".

A method "Correct and incorrect statements" presupposes the choice of correct variants by the students and justification of this choice. After getting the basic information (from a textbook, a lecture, a video) it is necessary to return to the statements and evaluate their authenticity.

A method "Thick and thin questions" accentuates the attention of students that there are questions that can be answered unequivocally (thin questions), and those to which it is not possible to answer definitely (thick questions). Thick questions are problematic questions, involving ambiguous answers. Examples of "thin questions": who ...; what ...; when ...; may it be ...; will it ...; could he ...; what's the name ... .; was it (there) ...; do you agree ....etc. Examples of "thick" questions: explain, why ...; why do you think ...; what is the difference ...; what will happen if etc.

This work helps to develop thinking and attention of students, as well as to develop their ability to ask " smart " questions. Classification of questions helps in finding answers, makes students think about the text and helps them to understand its content better. This method stimulates the dialogical speech of students.
A method "Insert". When reading the text, students note the following signs on the edge of the pages: $\mathrm{v}$ (information corresponds to what I know); (information contradicts my beliefs); + (information is new for me); ? ( information is contentious, incomprehensible). After reading the text with the marking, students fill in the "insert table" according to the signs. This method makes visible the process of accumulating information, the path from "old" to "new" knowledge becomes clear and precise, it provides thoughtful and careful reading.

A method "Reading / viewing / listening with stops" allows to work through the text in detail, and also to train the ability to predict, to discourse logically, to argue and convince, to examine the situation creatively.

A method "Two-part diary." (eg. Table 1). This technique is used when students themselves work with the text and then train each other on the question studied. During the explanation of the material such diaries are kept, consisting of two parts. The first part contains a summary of the material presented, and questions arise or not clear moments are fixed in the second part. Two-part diaries enable students to closely link the content of the text with their personal experience. 
“Great Britain".

Table 1

\begin{tabular}{|c|c|c|}
\hline Topic & I know & I found out \\
\hline $\begin{array}{l}\text { The Monarch and the } \\
\text { Cabinet. }\end{array}$ & \multirow{2}{*}{$\begin{array}{l}\text { Students } \\
\text { offer their } \\
\text { options }\end{array}$} & $\begin{array}{l}\text { The Queen is only a formal ruler. But she looks through all important } \\
\text { information and no Bill becomes a Law without the Royal Assent. }\end{array}$ \\
\hline $\begin{array}{l}\text { The Houses of } \\
\text { Parliament. } \\
\text { Etc. }\end{array}$ & & $\begin{array}{l}\text { There are } 2 \text { houses in the English Parliament: the House of Lords and the } \\
\text { House of Commons. The House of Lords consists of nearly } 1200 \text { peers, } \\
\text { created by the monarch on the advice of the Prime Minister. The House of } \\
\text { Commons is elected. They are } 630 \text { members. }\end{array}$ \\
\hline
\end{tabular}

A method "Table of arguments". One of the students gives arguments, and the rest should refute them or confirm them with facts from the text.

A method "Argumented evaluation" involves the use of pre-specified criteria for monologic or dialogical speech for self and mutual evaluation. This technique allows students to learn to evaluate each other's speech objectively, to argue their point of view, to be more attentive while listening to each other. In our practice we use such criteria as: content, communicative interaction, vocabulary, grammar, pronunciation.

It is important to note that all our lessons are held according to the scheme: challenge comprehension - reflection. The students formulate the tasks of the forthcoming work by themselves and at the final stage of a lesson return to them in order to analyze the results of their own or group work.

The use of methods of critical thinking development in the educational process involves interaction in groups in order to exchange experiences (both linguistic and social), to create conditions for discussions and debates on the topic under study, and to organize competent work with information resources. Such work help to develop the ability to solve the problems collectively, the ability to convey information clearly, the ability to defend one's point of view using arguments and evidence based on a critical analysis of the received information and their own experience. It serves to develop thinking, imagination, maintain cognitive activity and develop skills for building effective communication.

All this, in turn, leads to the formation of communicative self-efficacy. As it was noted by many researchers (A. Bandura, S. N. Gonchar, J.
Maddux, M. Scheer, etc.), a personal experience of achievements has the greatest influence on selfefficacy. The feeling of self-efficacy grows more if success is achieved independently, through efforts and through overcoming difficulties. It helps a person to believe in their ability to achieve the necessary results. After the successes has achieved, the expectation of efficiency is strengthened, while the negative impact of casual failures is weakened. Self-efficacy is also affected by indirect experience. It also grows when a person watches others successfully cope with difficult tasks. Conditions for solving complex communicative problems, problem situations are provided at our classes, including the using the techniques of critical thinking development.

\section{Summary and Conclusions.}

Today, the task of forming communicative selfefficacy of students in higher education becomes very important. This work assumes several stages: reflection of the learners of their communicative goals, abilities, attitudes, awareness of the ineffectiveness of some communicative actions and attitudes; definition of the most optimal communicative strategies, techniques, types of conflict resolution through observation of communicative actions of others, familiarization, information, joint search, awareness of the importance and need to develop their own communication potential; development of effective communication skills through mastering of communicative techniques, modeling situations that require flexible use of communicative techniques, changing their own communicative attitudes.

\section{References:}

1. Bandura A. (1998) Self-efficacy // Encyclopedia of human behavior. - New York: Academic press, 1998. - Vol. 4. - P. 71-81.
2. Belykh T.V. (2015) Struktura integral'noy individual'nosti studentov $\mathrm{s}$ raznoy stepen'yu kommunikativnoy samoeffektivnosti. Monografiya - M.: Mir nauki, 2015. - 70 p. 


\begin{tabular}{|c|c|c|c|c|c|c|}
\hline Impact Factor: & $\begin{array}{l}\text { ISRA (India) } \\
\text { ISI (Dubai, UAE } \\
\text { GIF (Australia) } \\
\text { JIF }\end{array}$ & $\begin{array}{l}=1.344 \\
=0.829 \\
=0.564 \\
=1.500\end{array}$ & $\begin{array}{l}\text { SIS (USA) } \\
\text { PИНЦ (Russia) } \\
\text { ESJI (KZ) } \\
\text { SJIF (Morocco) }\end{array}$ & $\begin{array}{l}=0.912 \\
=\mathbf{0 . 2 0 7} \\
=\mathbf{3 . 8 6 0} \\
=\mathbf{2 . 0 3 1}\end{array}$ & $\begin{array}{l}\text { ICV (Poland) } \\
\text { PIF (India) } \\
\text { IBI (India) }\end{array}$ & $\begin{array}{l}=6.630 \\
=1.940 \\
=4.260\end{array}$ \\
\hline
\end{tabular}

3. Gaydar M.I. (2008) Razvitiye lichnostnoy samoeffektivnosti studentov-psikhologov na praktike vuzovskogo obucheniya: Avtoref. dis. kand. Psikh. nauk. - Kursk, 2008. - 27 p.

4. Ignatova V.V., Pasekkina T.N. (2017) Kommunikativnaya samoeffektivnost' kak vazhneysheye kachestvo budushchego spetsialista. // International Scientific Journal Theoretical \& Applied Science. - 2017. - №5. 2017. P.161-164.

5. Kouts Dzh. (2011) Pokoleniya i stili obucheniya. M: MAPDO; Novocherkassk: NOK, 2011.

6. Lebedinskaya S.V. (2017) K voprosu izucheniya samoeffektivnosti cheloveka kak resursnogo kachestva u studentov gumanitarnogo profilya // Uchenyye zapiski ZabGU. Pedagogicheskiye nauki. 2017. T. 12, № 2. P. 60-65.

7. Meredit K.S., Stil L.L., Khram S. (1997) Kriticheskoye myshleniye: uglublennaya metodika. Pozitsiya IV // Podgotovleno v ramkakh proyekta «Chteniye i pis'mo dlya kriticheskogo myshleniya». - M.: Izd-vo «IOO» .- 1997.- 55 p.

8. Pasekkina T.N. (2017) Razvitiye kriticheskogo myshleniya v kontekste oriyentatsii budushchikh spetsialistov na samoeffektivnost'. Nauchno-analiticheskiy zhurnal «Sibirskiy pozharno-spasatel'nyy vestnik», 2017, №5.P.58-63.- Accessed: http://vestnik.sibpsa.ru/wpcontent/uploads/2017/v5/N5 58-63 (Accessed: 13.12.2017).

9. Khal'pern D. (2000) Psikhologiya kriticheskogo myshleniya. St. Petersburg.: Izd-vo «Petr», 2000. 512p.

10. Yulik O.A. (2014) Tekhnologiya razvitiya kriticheskogo myshleniya $\mathrm{V}$ formirovanii kommunikativnoy kompetentnosti v prepodavanii inostrannogo yazyka // Molodoy Uchenyy, 2014. - №2. - P. 890-892. Accessed: https://moluch.ru/archive/61/9072 (Accessed: 13.12.2017). 